\title{
The very recent fall and rise of Harris Tweed
}

This article is an edited version of the transcript oflan Denyer's BBC4 program Harassed Tweed, first broadcast in September 2009. Harassed Tweed, director: Ian Denyer; executive producer: Malcolm Neaum. First broadcast as part 2 of the series "Tweed" on BBC4, September 15, 2009. The program was part of "This Is Scotland," a BBC4 season that celebrated and examined aspects of Scottish culture, art, film-making, heritage, landscape, and psyche.

Tweed is the nearest thing the British have to ethnic national dress. Espoused by Edwardian gentlefolk and the new middle classes, it became the uniform for peacetime pastimes and spoke of heather-covered hills and fragrant glens. A fabric that looked and smelt like the land, its historical production was the work of artisans and skilled craftworkers in the sort of rustic industry that has all but disappeared from the British mainland. The statutory definition of Harris Tweed - in Scots Gaelic Clo Mhor, 'the big cloth' - is a tweed hand-woven by the islanders at their homes and finished in the islands of Harris, Lewis, North and South Uist, Benbecula and Barra (The Outer Hebrides) and made from pure virgin wool dyed and spun in the Outer Hebrides [Harris Tweed Act, 1993].

This is the extraordinary and very recent story of near disaster, hubris and tenacity, as Harris Tweed was almost lost to posterity...

\section{Crisis Looms}

Tweed, for centuries was a peasant cloth, was brought to public notice by King Edward VII (1841-1910), whose interest boosted the business of the bespoke tailors London's Savile Row, 800 miles south of the Hebrides. Contemporary tailor and Scot, Patrick Grant, of the top Savile Row bespoke house Norton \& Sons, offers his customers a personal guarantee that his tweed is authentic, hand-woven by an islander, at home, and finished in mills on certain islands in the Outer Hebrides [Note 1]. Subject to the Harris Tweed Act, legislation designed to keep the cottage in this cottage industry and protect the most noble of tweeds from forgers outside the islands, all genuine Harris Tweed bears the hallmark of 'the orb' ironed or stamped twice on every metre length as endorsement of its excellence. The current Tweed Inspector, George Graham, is in no doubt about the importance of his role. If the islanders lose the uniqueness of their 
tweed they lose everything. The purity of their cloth is part and parcel of what these people are.

Unlike most Harris Tweed weavers, Donald John Mackay is a freelance independent, selling his cloth directly to tailors like Grant. The woollen yarn he weaves into tweed comes from an island mill, and each week Mackay takes his finished cloth back to the mill to be inspected, washed and officially stamped. From afar his cloth may appear to be a single hue, but up close, the illusory and magical array of interacting colours, shades of the hills, the rocks and the water is revealed. But the beauty of Harris Tweed is more than its look and handle. It binds together its community of farmers, weavers, mill workers and wearers, each a single thread in the one, bright story that is as much about the past as the here and now.

This relationship between the mill and the weaver is central to the production of Harris Tweed. Tweed starts life in the mill as raw wool, dyed in a vast array of colours, then mixed to produce the subtle tones necessary for the woollen yarn. Most islanders speak Gaelic, as tangible a part of the Celtic legacy as the tweed. While the Gaelic language is supported by government grants, Harris Tweed must fight for survival in the market place. In 1966 seven million yards of cloth were woven. In 2006 it was less than a tenth of that. Disposable fashion culture closed the big mills in the island capital of Stornoway, and the American and Japanese markets, affected by dollar and yen losses, disintegrated in the 1970s and 1990s respectively. The island economy and infrastructure suffered and became fragile. With few other careers open to younger islanders, emigration in search of employment more regular than tweed making ensued. The Hebrides felt like beleaguered islands in a heathen sea, with a tweed industry in decline, observing the Sabbath and looking to an Old Testament God for answers:

Minister: Oh God our father in heaven. We cry unto our God pleading with you to come to our help so that as a community we can prosper in the way of generations past. And that our lives can be turned around once more and we can enjoy the prosperity that flows to us from the hand of Almighty God. Amen. 
And in their darkest hour, a 'textile saviour' appeared unto them, coming forth not from Heaven, but from Yorkshire. His name was Brian Haggas.

A millionaire textile magnate with sixty years experience of the rag trade, Haggas wanted a new challenge before retirement. He decided to 'rescue' the Harris Tweed industry, and in Winter 2006, he bought up the Kenneth Mackenzie Mill, where 95\% of the small volume of Harris Tweed still being made was produced. To islanders and tweed fanatics everywhere, the multitude of Harris Tweed patterns had always been its main attraction, but for Haggas this splendid variety was central problem:

Haggas: Eight thousand patterns. Each individually made at enormous cost over the years. That is the road to ruin. We set off by cutting the patterns down from eight thousand to four...

Eight thousand patterns cut to just four at the Kenneth Mackenzie Mill, and immediate loss of the supply of multi-coloured yarn to the remaining freelance weavers like Mackay who were still making 5\% of Harris Tweed for Savile Row tailors including Grant:

Grant: Essentially strangling the supply of colour to what ultimately is supposed to be a colourful cloth seems to me to be the wrong thing to do. I think restricting that supply seems to me counter to everything that Harris Tweed stands for.

At the Kenneth Mackenzie Mill, however, there remained a collection of forbidden traditional Harris Tweed patterns. According to Plant Manager John Alderson, these were great in their variety, "depicting the landscape around the isle of Lewis...the shoreline...the pebbles...the moor...the sea vigorously blowing across like the spray off the top of the waves..." and, while it had previously been "up to the customer, what they wanted is what we would make and sell", that was now all changed: "We've cleared all that out. We're trying to discipline the customer. That's the four that we're doing". 
With the supply of newly woven old-school Harris Tweeds drying up, and only four designs now being made, Grant had to turn to a London-based woollen merchant supplier of vintage tweeds to keep his customers satisfied. W. Bill and Company's cramped basement is an Aladdin's cave of tweed from the Outer Hebrides and from Shetland, from the Scottish borders and Donegal [Note 2]. Many of the most ancient Harris Tweed designs are held in stock, but only as long as stocks last. For Grant a crisis loomed: he could buy tweed made elsewhere, but he is a purist, and his tweed-fancying clientele should only have the best. Harris Tweed - but:

Grant: ...these people are not going to use Harris Tweed if all they can have is brown, brown, brown, slightly blue, grey and brown. With all due respect to the guys up there, they're fairly drab. So we're really stuck. I just get the feeling that they don't understand how passionate people are about their product. You know the people who wear this cloth are not wearing it because they need something to keep them warm. They're wearing it because they want to feel part of this romantic history of the highlands of Scotland and if you churn it out by the yard in four different colours you will end up with something that's just another cloth, and that would just be a disaster.

But Haggas had a greater plan than simply making miles of cloth at the Kenneth Mackenzie Mill. He now intended to cut off the supply of tweed to all other garment makers - and seize the entire world market in Harris Tweed jackets. Over the winter of 2007-08 there was a production bonanza - one hundred and fifty thousand metres of fabric woven in sixteen weeks. Harris Tweed, in four colours, made up into a single jacket shape in Chinese factories, but packaged for authentic 'Britishness' with racing green boxes and mahogany coat hangers. The results of the massive output by the weavers and the mill workers filled the warehouse with seventy-five thousand jackets, which Haggas planned to supply to any retailer, in any size, anywhere, at a few hours' notice.

And then came the order to stop. The Harris Tweed jackets just weren't selling. Haggas' strategy switched from manufacturing to selling, and the Harris Tweed weavers were laid off. At the church in the village of Shawbost the sermon was eerily appropriate: 
Minister: And he intrudes into this place of harmony. Someone who cannot tell the truth. A liar from the very beginning. An intruder who is described as The Serpent. The devil himself. And his goal in this world is to destroy all the good things that God has created. All the good things that God has given you and I to enjoy, he is intruding in order to destroy that.

The fortunes of the weavers, the future of the island economy, the fate of Harris Tweed itself, now appeared dependent on just one thing: selling seventy-five thousand jackets in subtle shades of mud. The forecast was bleak and island morale was at rock bottom. But, three thousand miles away in New York, the alarm was sounding deep within the Scottish diaspora. No one loves Scotland like a Scot who lives somewhere else, and at the Manhattan offices of businessman Alan Bain, President of the Scottish American Association and multi-million dollar real estate tycoon, patriots were summoned to a council of war:

Bain: I feel this great sense of urgency with the protection and preservation of the Harris Tweed industry, and I get intensely frustrated because I don't feel this sense of urgency being recognised by the people that stand to lose the most, if it isn't preserved and protected. We're supporting an endangered culture...if Harris Tweed were a Japanese product it would have been declared a national treasure, and with that designation it would have been both protected and promoted. Why isn't Scotland looking at some of its crafts in this way? Tomorrow is too late, you know, it has to be today.

Tweed is highly prized in the United States, and Bain knew that his fellow Americans were more tweed-aware than home grown Scots. Bain, a man of action, took action, buying into the tiny Carloway Mill on Harris. With his transatlantic blend of altruism and canny opportunism, Bain dug into his own coffers to fund the battle for the soul of Harris Tweed.

But Bain wasn't the only one spotting opportunities. While he travelled the low-tech and artisanal road, ten miles away a group of disgruntled tweed technicians and venture capitalists envisaged a high-tech, high-volume business and enlisted former labour 
minister and press-magnate Brian Wilson to help realise it. Wilson and his colleagues re-opened the mothballed Shawbost Mill, and reached out to all those old customers who still lust for Harris Tweed but couldn't get any from Haggas.

There were now just two tiny mills - Carloway and Shawbost - able to make all the new Harris Tweed on earth. Both had sprung into action, and freelancer weavers like Donald John Mackay were also back in business, with these mills supplying the yarns needed to weave traditional, multi-coloured tweed for Grant and his like in Savile Row.

\section{Harrassed Tweed}

Harris Tweed has a loyal following in enthusiasts like London-based fabric designer, Guy Hills with his mission to render the world of men's clothing more colourful. His chosen medium is tweed:

Hills: When I first went to my tailor I was full of excitement. I wanted really vibrant tweeds, the sort of thing you'd expect for Bertie Wooster playing golf - and they didn't have any. Everything was just all a bit drab.

Hills' antidote was to launch his own tweed range of cloth and finished garments, Dashing Tweeds [Note 3], and now he wanted to enrich the gene pool of his tweed collection with something more - the DNA of Harris Tweed. Hills sells his tweed garments through top-end men's stores and his cloth on-line to the cognoscenti. If he could get the weavers to create his own eye-popping Harris Tweed range, his urban designs would acquire gold-standard tweed credibility. Harris Tweed is unlike any other, romantic and luxurious, the landscape of the Outer Hebrides rendered in cloth. Up close, the secret of the subtle shades is revealed: a blending of many colours, a pointillist adventure in wool, available by tradition in eight thousand designs. This tweed is lustre, patina, fresh air and northern light. 
Another London tweed specialist, Katherine Hooker, dresses ladies who want to wear the best of British tweeds. Her business depends on getting hold of it, and keeping her customers satisfied has become increasingly tricky:

Hooker: People who specifically want Harris Tweed - I don't know what to tell them, because I don't know myself. Apart from some guy's gone up there and bought one of the mills and it's really affected the whole industry. No one's really sure but something's changed because what has been a reliable source since I started the business, and it's suddenly not. There's a huge question mark over whether it's going to be available in the future.

For Hooker the problem more than sartorial: when Haggas took over the biggest mill of all - the Kenneth Mackenzie Mill - it was to make tweed jackets, but he also cut off the supply of coloured yarns required for the manufacture of the old-school patterned tweeds that Katherine needs for her business. Back on the Outer Hebrides, the tweed industry was in turmoil. A year ago, Haggas had been weaving Harris Tweed in quantity. By February 2009, a hundred Kenneth Mackenzie Mill weavers were twiddling their thumbs waiting for Haggas to sell the thousands of jackets he had in storage in Yorkshire. Recession was in the air, and few consumers wanted a new Harris Tweed jacket. Meanwhile, independent weavers like Mackay also awaited Haggas' next move as their livelihood and well being too depended on what the Yorkshireman did next. Haggas' cash flow problems had gone critical, however, and that meant trouble at the mill.

Haggas: We are going to simplify procedures and streamline everything. Rotten job today, making people redundant. I mean nobody likes to do that. We've made so many redundant, but you know we just don't need them...

Haggas' drive from the airport took him past villages where once every house was a weaving shed and the rhythmic clatter of thousands of foot-powered looms was a guide for travellers on the road. The Kenneth Mackenzie Mill was already sparsely populated because in May 2008, with no more tweed to make for the unforeseeable future, thirty- 
six mill workers had been laid off. Nine months on, hundreds of metres of tweed still lay in racks ready to be made into more jackets when the thousands in stock had been sold, and more redundancies were imminent. Haggas moved to retain only a skeleton management team at the Kenneth Mackenzie Mill, citing global recession and admitting to feeling that he had let his workers down. Within months, that skeleton was reduced to nothing.

Haggas: The islanders here have the feeling that the world is crying out for Harris Tweed it is nothing of the sort.

During Haggas' reign as the King of Harris Tweed, his mill produced 95\% of the island's output, and he had installed millions of pounds worth of new equipment. Now the two tiny mills that had 5\% of the market and running on old and second-hand equipment Carloway and Shawbost - were going to be making all the Harris Tweed in the world.

Worker: I was absolutely devastated.

Worker: Everyone was gobsmacked. Speechless more or less.

Worker: It was the best job I ever had...

Haggas: ...we have more than seventy thousand jackets in store and we have got to sell them and we cannot produce any more 'til we start really shifting them...

Worker: If you can't sell it there's no point producing it.

Worker: I grew up I could see the chimney of the mill from my house. My grandfather worked here. My grandmother worked here, my mother worked here. My wife worked here. You know it was the backbone of the town really. It's only now I appreciate how good it was, now it's not here.

Meanwhile in London, Harris Tweed aficionados like Hooker are worried. They cannot get a clear message from the Outer Hebrides about production or stock, and have clients wanting to match traditional tweeds:

Hooker: It's a blue version of that and it's just so beautiful. If I can't get that again and I don't think I can... I've been asking for it for over a year and I just can't get a straight 
answer. I think they're all in shock, to be honest, up there, so no matter how many times you call them no one seems to know what's going on. So I think probably we're going to have to get on a plane and go up there, with some other people who are also being affected by it and find out.

Hooker's 'tweed posse' included tweed entrepreneur Guy Hills and his business partner and weaver Kirsty McDougall. They went north seeking clarity on whether Harris Tweed was dead and gone, and to seek the textile remnants of a glorious Harris Tweed past, rumoured to still be retained in storage somewhere in the Outer Hebrides. That they should have to do so begged a question as to the function of the body tasked with speaking for the whole industry, the Harris Tweed Authority, and its newly appointed chief executive, Lorna Macaulay [Note 4]. Macaulay, however, had seized the day, determined that Harris Tweed would survive her watch, and set out for the biggest tradeshow in the fabric world, Premiere Vision, Paris.

Macaulay: Such have been the headlines in recent times that folk actually thought that Harris Tweed had died and we had gone away, so it's really helpful for Harris Tweed Hebrides to have a presence here...it's just to let people know that we are still here. It's as fundamental as that.

In the glory days, Harris Tweed was a PV regular fixture, and Macaulay's modest Harris Tweed booth was a signifier of reduced status. Nevertheless, the reappearance of Harris Tweed at the event was attracting interest from far-flung corners of the globe and this was a boost to the beleaguered Harris Tweed Authority. Meanwhile both Carloway and Shawbost Mills were taking action. The former, under the commuter management of New York's Alan Bain, was energetically pressing the 'preservation and protection' button:

Bain: Outsiders have recognised what it represents, and I get intensely frustrated because I don't feel this sense of urgency being recognised by the people who stand to lose the most of it isn't preserved and protected - the people on the island. I mean, as much as they don't want to lose it, they don't appreciate what has to be done to keep it going. 
Bain had retained top PR guru Martin Hunt to persuade Italian carmaker Alfa Romeo in Edinburgh to commission some limited edition Harris Tweed seats covers for the launch of their new model, the Meto:

Bain: It's struck me as a wonderful opportunity to align ourselves with high style, high fashion and youth. So for me I'm delighted to have the opportunity to see how we can explore that with your organisation how we can best do that for mutual advantage.

Bain and Hunt's emphasis was non-traditional, with "the younger age bracket" and "style and passion" to the fore, and "vibrant, contemporary...something that will compliment the leather. Yellow. Lovely colour..." the overarching flavour of the discussion.

While Bain was working with the Italians, Shawbost Mill's Brian Wilson was entering collaboration with rising Scottish menswear designer Deryck Walker, soon-to-be winner of the Scottish Designer of the Year Awards [Note 5]. Again, colour was prominent in the language, and the need to find someone who would rejuvenate an industry already associated with four drab shades. The On Off independent fashion show proved to Wilson that Walker, with his colours inspired by Glasgow's urban local rather than the heathery landscape of the Outer Hebrides, was the designer for a Harris Tweed renaissance.

Wilson: When I saw the colours that Deryck was using I was delighted, because I thought again this shows what can be done with it. And the other thing about Deryck's clothes is they are all wearable. I mean they are bright and exciting but they are not beyond the pale for people wearing them...

With Bain and Wilson actively seeking innovative means by which to keep Harris Tweeds alive and contemporary, the 'tweed posse' was on Harris searching for the fabled cache of lost tweeds. The 'Turin Shrouds of Tweed' were in fact languishing in an old shed right on the waterfront, banished there as 'old-fashioned' and 'commercially 
inefficient' by Haggas. According to legend, there were more than eight thousand patterns of Harris Tweed, and many were there - ends of rolls, experimental designs and orders uncollected:

Hills: This is like hidden treasures! These have all died out which is why they've ended up in the tweed graveyard here. Just left for someone like me to appreciate them. The reality is I probably wouldn't have set up Dashing Tweeds if all these things were out at the time. My tweed desire would have been satiated.

Hooker: I'm just about to run out of this exact tweed. Now I know I can get it... Hills: I'm going to buy these...I want to keep hold of it in case it goes missing! Look at this look at this!

Being amongst so much vintage tweed sparked certain exuberance amongst the visitors, and they now needed to find a mill that would produce some new old-style tweed. In Stornoway, at the Harris Tweed Authority, the imminent arrival of the expeditionary party, people who might get weavers weaving and dyers dyeing, caused a stir. The Carloway and Shawbost Mills were willing to oblige.

Hooker: Well we're really excited because their yarns that we just had a look at are absolutely fantastic, and they'll be able to weave what we want, so we established that really quickly. And this makes me feel excited because I know I can get it again... McDougall: The qualities, the colours are beautiful. Hooker: It should be available and it is available. I don't think it's breaking the bank to keep it available.

Mission was accomplished. The trip had been a success. And while Hills and McDougall placed their order for genuine Harris Tweed yarn, at an Alfa Romeo showroom in Edinburgh the new Meto was launched with its limited edition Harris Tweed seat covers.

Hunt: It so special, because it's linking two iconic brands together. 
Italian Consul: It's a good example of how Italy, Scotland, Great Britain can do things together. Tangible things. It feels good. Not so rough after all. On the contrary.

Bain: That to me is the message I'm going to be carrying back to the islands. You know Harris Tweed is not just about men's jackets.

Hunt: I've done some quite exciting things in my life at a global level, but this one here, in a funny sort of way, is so utterly important to me because of my enthusiasm for using iconic Scottish brands.

And while Scots-Italian relations were being sealed, Deryck Walker travelled to Shawbost Mill from Glasgow to meet Ken Kennedy, the colour blender who would interpret his tweed visions. Walker's task will be to grasp centuries of tradition and give them a respectful twist. He must win the hearts of young men who want style, without upsetting islanders who don't want their tweed messed around with. The colour blending is where Harris Tweed begins to form: raw wool dyed and then blended together in great clouds of colour, spun into the yarns that will be woven into tweed. Having the right eye for this alchemical process is everything. Kennedy can tell which mix of dyed woollen yarns will, when twisted together, produce the shades closest to what designer Walker desires. It is one of the most skilled jobs in the tweed making process.

Walker: I think we're looking at this in navy and the yellow...

Kennedy: Yes we have a stronger yellow.

Walker: Yes that is it that is it.

Kennedy: It's a golden yellow.

Walker: It's really brilliant. I'm really pleased with it... I think these two are the ones that will get people thinking about it...

On the outskirts of Stornoway, however, at Haggas' Kenneth Mackenzie Mill, there was only an eerie silence. Manager John Alderson is the last man standing, and he has been given his notice to quit. He spoke up openly: 
Alderson: It's diabolical that we've got such a good plant that we can't put it into use. He sat me down in his office and he said I'm going to close the plant for twelve months and I'm making you redundant. And at that point the world just fell from beneath me... Just doing the four patterns for a plant like this was just playing with peanuts really. I don't think just jackets is enough...

Haggas in Yorkshire saw the problems differently, however, attributing the downfall of Harris Tweed to customer taste:

Haggas: I think the main mistake we made, I did, and it was totally my fault, is we misjudged our customers - I've said they thought of Harris Tweed with fondness and nostalgia but they thought of it as yesterday's product...

That was not the word on London's Savile Row, though, where Hills and McDougall eagerly awaited the arrival of tweed yarns from Carloway Mill for creation of their new Urban Harris Tweed sample designs. Hooker had received her package of Shawbost Mill swatches and samples that will make her life easier and her business viable again. In Glasgow, Walker had also received a parcel from Shawbost Mill where one of the younger weaver was persuaded to throw tradition to the winds and weave something never seen before - Harris Tweed in tones inspired by a Muslim grocery shop.

These might be baby steps, but Harris Tweed was all but dead - in fact many thought it was buried. Now, if the word spreads, the weavers and mill workers could rise up like an Arthurian army and take over Harris Tweed production again. In the vacuum left by Haggas' stalled initiative, with his giant Kenneth Mackenzie Mill and its newly installed state of the art machinery lying silent, the two small mills sprang up to meet the demand for tweed in a variety of colours. The larger mill - Shawbost - began working with award-winning designer Deryck Walker to bring Harris Tweed to a new generation, while at the tiny Carloway Mill, US entrepreneur Alan Bain began producing high-end luxury tweed on a smaller scale. Now that sustainability is an ascendant design theme, there could be a golden future for Harris Tweed. 
The inhabitants of the Outer Hebrides have come through the worst crisis in the long history of their famous tweed. Haggas came as a saviour, but left having sacked the workers and shut down his mill. Some of the mill workers that Haggas let go are now making tweed, keeping tweed-making skills alive, and islanders on the islands. On London's Savile Row, Patrick Grant is now able to consider offering Harris Tweed garments in his new ready-to-wear collection:

Grant: We are totally delighted. Shawbost and Carloway are up and running again. Yarns are being produced and you can get turquoise and bright green and lilac and the interesting colours that everybody enjoys wearing. And you know we wouldn't be sitting here if it hadn't been for those two mills getting up and running. It is obviously tremendously positive for them, but - you know ultimately I can't help thinking that without some additional assistance or an additional push, it's going to go back where it was before...

Can the ultra-conservative islanders adapt to survive in the slick world of modern business, and keep their precious tweeds authentic?

\section{Hanging by a thread}

Grant is right to be cautious, because the long-term fortunes of Harris Tweed still lay in the hands of Haggas. He still claims that the Kenneth Mackenzie Mill is only mothballed, and that he's coming back. But if he is going to make tweed again, Haggas will need to find himself a new workforce. Weavers and mill workers not engaged by the two smaller mills, drifted away from tweed making to take steadier employment taxi driving or at the new call centre in Stornoway. For people who have spent their lives with cloth, born and bred to the production of Harris Tweed, and whose very identity comes from it, these soulless alternatives are hard labour.

Before he restarts production on the island, Haggas needs to sell his seventy-five thousand jackets still in storage. Stock of jackets is dwindling, but slowly, and he has sold around five thousand. The unsold jackets are clogging the warehouse, and keeping 
the Kenneth Mackenzie Mill empty costs money. But Haggas is not giving up, and he and his management team resort to the cutting-edge methods of putting a jacket up as a competition prize in the region's newspaper, discounting costs, and printing a new sales brochure. Having laid off his weavers and mill workers, Haggas is romanticizing the story of the desperate and starving pioneer weavers of the nineteenth century in an ultimate publicity stunt: Harris Tweed: the Movie. This epic, rumoured to have cost more than a million pounds, mixes historical events and contemporary drama. It stars Haggas, as a final act of hubris:

Haggas: I knew nothing about films, absolutely nothing, but we're learning. I think they've done a superb job. The best thing about it is I think it's emotional. It is to me - I shed a tear every time I see it.

But instead of trading on a romanticised version of its past, the cloth might be better promoted as the product of tomorrow...

Deryck Walker has come to Japan, the place where new marketing trends begin. He has designed some funky new Harris Tweeds for Shawbost Mill, and is about to launch his tweed clothing range, a risky blend of ancient and modern. He meets Japanese retail guru Hirofumi Kurino at a seminar for fashion designers from around the world. Revered, as an oracle of what's hot and what's not, Kurino believes globalisation has had its day:

Kurino: It makes all the cities the same. Our customer is not excited with this anymore. Once I went to Scotland. I was really impressed by the atmosphere. Not poisoned by the global marketing. Japanese people like these things very much. We have a lot of things in common. You can be very proud of your culture. Japanese people like Harris Tweed very much. We are always open to buy and use your fabrics.

Kurino has confirmed that Deryck Walker is on the right track. The time has come again for Harris Tweed, and it is not in the shape of Harras' one-shape jackets. 
Walker: We live in this world, where things come and go every day, and if we can keep the things we've got left it would be fantastic. We've got an icon in Harris Tweed and I think, at a time when things are disappearing, that it's really important that we hang on to those things because we don't have many left.

Walker and Shawbost mill are ready to take Harris Tweed to a new generation with a growing appetite for products that are genuine. And they do that via Paris, in a happening arrondissement. Most of the audience are fashionably very late when Walker's show starts, but this is history in the making. The late arrivals are missing the first sight of a revolution, Harris Tweed as nobody has seen it before in Mediterranean hues a million miles from the sort of hairy heather-mixture shades worn by old men. This is urban tweed with street credibility and no hint of country estate stuffiness. Walker's startling new designs take the cloth to a new fashion-conscious audience: he has changed Harris Tweed, and the tweed has changed him:

Walker: I've realised that I'm a Scotsman. Very patriotic. I think the guys at the mill were really proud of the patterns. This is just the future - the two great mills that are left can get on with it and they're doing really well.

At the third and smallest mill on the island, Alan Bain also believes that he can detect a groundswell of change:

Bain: There clearly has been a seismic shift in the way people think of luxury. To move away from the bling. You know people value the cloth because it can be handed down from generation to generation. It was therefore very prudent, very frugal, to buy quality cloth that lasted for a long time. It wasn't just discarded after a season. And I think sustainability suggests that this has a real value, and I think that if it's properly presented in the market place it has a real possibility of revival because it does meet so many of our current expectations.

Bain wants to access the womenswear market, to make Harris Tweed softer, lighter, and sexier. His creamy prototype tweed is made with lambswool, and Bain would really like 
to talk about adding super soft cashmere yarn to the Harris Tweed mix, though to fundamentalists, that's tweed treason.

Bain: The issue is to what degree should Harris Tweed be changed, whether we can do it comfortably under the Harris Tweed brand, without impacting, losing anything. It was understood to be a heavy, itchy fabric, for the hunters and shooters of the world, but you know that's a limited market place, so even though you have a great brand name it's associated with some negative qualities. Well that's no longer the case...

Hoping to get some publicity for it, Bain has released the roll of ultra-light tweed to island dressmaker Anne McCallum, who has just received a remarkable commission from top Gaelic singing star Alyth McCormack for a tweed wedding dress [Note 6]. Alyth McCormack is a celebrity who has seen the world from the stage she shares with Celtic folk stars, The Chieftains and Maire Brennan. On tour she could wear any designer gown, but she always appears dressed in Harris Tweed and she takes pride in being a tweed ambassador. It is Alan Bain's hope that the world's first lambswool Harris Tweed wedding dress will get people talking, and the bride-to-be is already impressed:

Alyth: It's very smooth. It just feels very nice to the touch. You know if you were doing a blind test with anybody, they wouldn't know it was Harris Tweed at all.

Few would consider Harris Tweed as a suitable fabric for a wedding dress, but for the Gaelic singer, there was never going to be anything else. Alyth is an islander, who has championed this cloth onstage the world over. It is her heritage. Bain's revolutionary super lightweight lambswool Harris Tweed is an experiment, but it is one way the cloth might go, a softer fabric for a new age, re-interpreted structure for a tweed future.

In wanting to tamper with the cloth, Bain is up against an ancient regime of tweed guardians devoted to the integrity of the Harris Tweed brand, and its timeless qualities. Harris Tweed is admired not only as a wonderful cloth, but for its romantic associations. It evokes this landscape, the people who have made it for generations, and their way of life. Enthusiasts are buying into an ideal. But are the islanders, who live amongst all this 
beauty, too close to it to fully appreciate its allure? And what about those who do understand what they have in the cloth - and are apprehensive that the world might want to change it? To assist the islanders towards greater awareness of its prestige and value, to boost morale, and to emphasise the critical mixture of modernity and tradition necessary for Harris Tweed's survival, Harris Tweed Authority chief executive, Lorna Macaulay, steps in with her Stornoway Festival of Tweed.

The international fashion-pack arrives for the catwalk show celebrating the work of the mills, and singing the praises of the cloth to the people who make it. Patrick Grant has been invited to deliver a motivational keynote speech. He wants to help the industry in any way he can, and from his perspective in the bespoke tailoring industry, he knows Harris Tweed could have a great future if marketed correctly:

Grant: There's a fine line between cottage industry and something that they find quaint, because I think that ends up being the death of it. It's the love and the passion of the people that makes me and my customers want to buy it.

The charm of the cloth itself is that it's made by islanders who are themselves - in the very best sense of the word - slightly naïve, and it's a very charming naïveté, and I think that's what helps sell the product, the island and the people. But at the same time, it's no good being charming and producing this wonderful thing if nobody ever sees it or hears about it.

Before he gives his speech to the weavers, Grant has some research to do. He wants to inspire pride in their product, but is it possible to buy a Harris Tweed jacket on the isle of Harris? Stornoway is dripping with 'Scottishness', but Harris Tweed jackets are elusive. There is one place, however, with a good stock - the charity shop:

Manageress: We do get a lot of people looking for Harris Tweed.

Grant: But the thing is we've looked all over the island and it's very hard to get a new Harris Tweed jacket.

Manageress: Oh, it's impossible! 
The fact that you can barely find the island's signature product in the capital is no joke, and something the Harris Tweed Authority might address...

At the Festival of Tweed venue, the models are in make-up, the audience is assembling, and Grant, one of 2008's fifty best-dressed men on the planet, has arrived [Note 7]. This is an event celebrating all the mills and their products. Haggas is absent, but one of his jackets is modelled by a local, who takes the opportunity to express his anger, and applauded by the audience. When the Tweed Festival catwalk show has finished, amongst the weavers there is a buzz of excitement, island style, for the appearance of the main speaker. The weavers are a restrained crowd, but they are listening:

Grant: The parallels between Savile Row and Harris Tweed are enormous. Every single suit is sewn and cut by hand and it's done locally, it's all done on Savile Row, and what you've got here is every bit as special. Every person here has a responsibility to share their passion for what they do and to spread that message. Somehow you've all got to work to get that into all generations of the population and people of every nation who don't know about it, and if they had the opportunity to see what I've seen, and see what it is that you do, I feel very confident that they will fall in love with your tweed and your island and you as people. I - for one - would absolutely love to see it thrive and prosper, as it should.

The people we deal with are educated people that just have enquiring minds anyway, and want to know about things, to understand who's made it and how they've made it, and that extends down to everything in their life - they want to know where their food comes from, which field the cows graze in. You know, the wool comes from this island, it's dyed here, and you can't get more environmentally friendly than this!

The weavers listen. Later, Grant speaks more candidly:

Grant: I think the problem they are going to face is that anyone of any substantial size Brooks Brothers, Marks and Spencers, Ralph Lauren - anyone who needs a substantial amount of cloth, I think they are going to struggle to get it out there. That means they'll 
spend their time doing smaller orders and they'll never get the bigger orders that they need to actually get themselves back on their feet. If this were Italy, the national government would say this is something of national importance and we're going to make sure that it survives. But it isn't.

Both Shadbost and Carloway Mills are currently making something ancient modern, but both are small ventures. Even working flat out, they are not going to be able to produce the volume of cloth that once made Harris Tweed the most important part of the Hebridean economy. Only one mill could make that difference. The two working mills would need to expand massively to make as much tweed as Haggas' Kenneth Mackenzie Mill could make. It is in Haggas' power to give the weavers and mill workers a secure future, but to do that he would have to reopen his mill and take orders from other manufacturers - in large volumes. Haggas set out to control the entire world supply of Harris Tweed, refusing to make cloth for anyone else. Harrods have taken thirty of his jackets, but sixty-nine thousand, nine hundred and seventy to go.

A postscript from Kirsty McDougall, weaver born on Lewis, and co-founder of Dashing Tweeds:

...our visit to the Isles of Lewis and Harris was imperative to understanding the heritage, production methods and integrity of Harris Tweed. My first experience of weaving was watching this process on the Isle of Lewis as a child and I'm sure this has had an effect on my chosen career and fascination with lifting shafts, creating structure and blending colour to create cloth.

Dashing Tweeds looks to the surrounding landscape of London to inspire cloth designs. Colours of wet pavement, red brick, double yellow lines and the parks and architecture of the city inspire fabrics designed to function and endure within the urban landscape. The icon of tweed, Harris Tweed, provides this model for working albeit with a very different source of inspiration. Harris Tweed is wholly produced on the island and its identity is intrinsically bound up in the landscape and heritage of its makers both visually and in its tactile qualities; thick, rough and protective. It is interesting that something so beautiful is 
produced on an island where there is a Calvinist anti aesthetic in much of the architecture that is built on the landscape.

We have since commissioned our own Dashing Harris Tweed and have worked with other designers who want a piece of the quality and heritage of Harris. The methods of producing Harris, being entirely local, are relevant in a climate that calls for greater consideration of sustainable production methods. We hope to continue our relationship with Harris, testing our ideas for innovation and production within the heritage and integrity of Harris Tweed...

The Harris Tweed industry is by no means home and dry. But should something so important to a community and its culture be subject to the buffetings of the market place? Or should it be cherished and subsidised like the Gaelic language and the heritage that represents? The jury's out !

\section{Notes:}

1. Norton \& Sons, www.nortonandsons .co.uk (accessed December 20, 2011).

2. W. Bill and Company, www.wbill.co.uk (accessed December 20, 2011).

3. Dashing Tweeds, www.dashingtweeds.co.uk (accessed December 20, 2011).

4. Harris Tweed Authority, www.harristweed.com (accessed December 20, 2011).

5. Deryck Walker, www.deryckwalker.net (accessed December 20, 2011).

6. Alyth McCormack, www.alyth. net (accessed December 20, 2011).

7. UK Esquire and $G Q$ magazines, 2008, www.blackbookmag. com/article/industryinsiders- patrick-grant/7825 (accessed December 20, 2011). 